\title{
[Regular Paper] \\ Nickel(II) Complex Bearing Fluorine-substituted $\alpha$-Diimine Ligand Immobilized in Fluorotetrasilicic Mica Interlayer as Heterogeneous Catalysts for Ethylene Oligomerization
}

\author{
Hideki Kurokawa $^{\dagger 1) *}$, Ryota OGawA ${ }^{\dagger 1)}$, Kazuhiro Yamamoto $^{\dagger 2)}$, Tsutomu Sakuragi $^{\dagger 2)}$, \\ Masa-aki OHSHIMA $^{\dagger 1)}$, and Hiroshi MivRA ${ }^{\dagger 1)}$ \\ †1) Graduate School of Science and Engineering, Saitama University, 255 Shimo-okubo, Sakura-ku, Saitama 338-8570, JAPAN \\ ${ }^{\dagger 2)}$ Polyolefin Technology Center, Japan Polychem Corp., 1 Toho-cho, Yokkaichi, Mie 510-8530, JAPAN
}

(Received January 15, 2014)

\begin{abstract}
Heterogeneous $\alpha$-diiminenickel(II) catalysts were prepared by the direct reaction between nickel(II) ionexchanged fluorotetrasilicic mica and the ligand $\left[\mathrm{Ph}{ }^{\prime}-\mathrm{N}=\mathrm{C}(\mathrm{Me})-\mathrm{C}(\mathrm{Me})=\mathrm{N}-\mathrm{Ph} ; \mathrm{Ph}^{\prime}=\mathrm{C}_{6} \mathrm{H}_{5}-, 2-\mathrm{FC}_{6} \mathrm{H}_{4}{ }^{-}\right.$, 4- $\mathrm{FC}_{6} \mathrm{H}_{4}^{-}, 2,4-\mathrm{F}_{2} \mathrm{C}_{6} \mathrm{H}_{3}-$, and 2,4,6- $\mathrm{F}_{3} \mathrm{C}_{6} \mathrm{H}_{2-}^{-}$. When the prepared procatalysts were activated by a conventional alkyl aluminum compound, such as triethylaluminum or triisobutylaluminum, the high activity for ethylene oligomerization was readily obtained with the formation of linear $\alpha$-olefins. The activity of the catalysts increased with the addition of fluorine atoms on the phenyl groups in the ligand, and the maximum activity ( $420 \mathrm{~g}-\mathrm{C}_{2} \mathrm{~g}-$ $\mathrm{cat}^{-1} \mathrm{~h}^{-1}$ at $0.7 \mathrm{MPa}$ and $50{ }^{\circ} \mathrm{C}$ ) was obtained by the catalysts containing 2,4-difluorophenyl groups, because fluorine atoms decreased the electron density of the nickel center. The oligomers were formed in good accordance with the Schulz-Flory distribution, and the values of the distribution constant were within 0.53-0.65. The selectivities of the linear $\alpha$-olefins were not less than $90 \mathrm{~mol} \%$ in all the runs. During all the oligomerization runs, long induction periods were clearly observed, but the period was shortened when the reaction temperature was raised. It seemed that the characteristic catalytic behavior was due to a complicated activation mechanism derived from the specific layered structure of the procatalysts.
\end{abstract}

\section{Keywords}

Layered clay mineral, $\alpha$-Diiminenickel complex, Clay mineral support, Ligand intercalation,

Alkyl aluminum co-catalyst

\section{Introduction}

Considerable attention has been paid to the development of new catalysts for the production of linear $\alpha$-olefins based on late transition-metal complexes having a neutral ligand, because these complexes showed a high catalytic activity for both the polymerization and oligomerization of ethylene ${ }^{1) \sim 5 \text { ) }}$. As a first important report, nickel(II) complexes bearing a sterically lesshindered $\alpha$-diimine ligand catalyzed the oligomerization of ethylene to form $\alpha$-olefins when the complex was used in the presence of methylaluminoxane $(\mathrm{MAO})^{6), 7)}$. These catalysts showed a high catalytic activity and selectivity to linear olefins under mild reaction conditions.

The electronic and steric effects on both the catalytic activity and the selectivity of linear $\alpha$-olefins were systematically investigated by Helldörfer et al. using the

DOI: dx.doi.org/10.1627/jpi.57.146

* To whom correspondence should be addressed.

* E-mail: kuro@apc.saitama-u.ac.jp nickel complexes bearing a halogen-substituted $\alpha$-diimine ligand; the nickel complexes bearing an $o$-, $m$-, or $p$-fluorine-substituted $\alpha$-diimine ligand showed a moderate catalytic activity and only oligomers were formed in all the complexes ${ }^{8) \sim 11)}$. Apart from the $\alpha$-diiminenickel(II) complexes, a large number of nickel(II) complexes consisting of neutral ligands, such as diimine, iminopyridine, bis(imino)pyridine, iminoquinoline, bipyridine, and phenanthroline derivatives, have been developed ${ }^{12) \sim 52)}$; most of these complexes selectively afforded light olefins such as butenes and hexenes.

Recently, we developed iron and nickel complexes immobilized in clay mineral interlayers, and these catalysts acted as useful heterogeneous catalysts for ethylene polymerization by their activation with conventional alkyl aluminum compounds ${ }^{53) \sim 56)}$. These catalysts are readily prepared by the direct reaction of a metal ionexchanged clay mineral and an appropriate ligand in a solvent. Moreover, the production of ethylene oligomers using these heterogeneous catalysts was easily achieved by modification of the ligand structure in the 


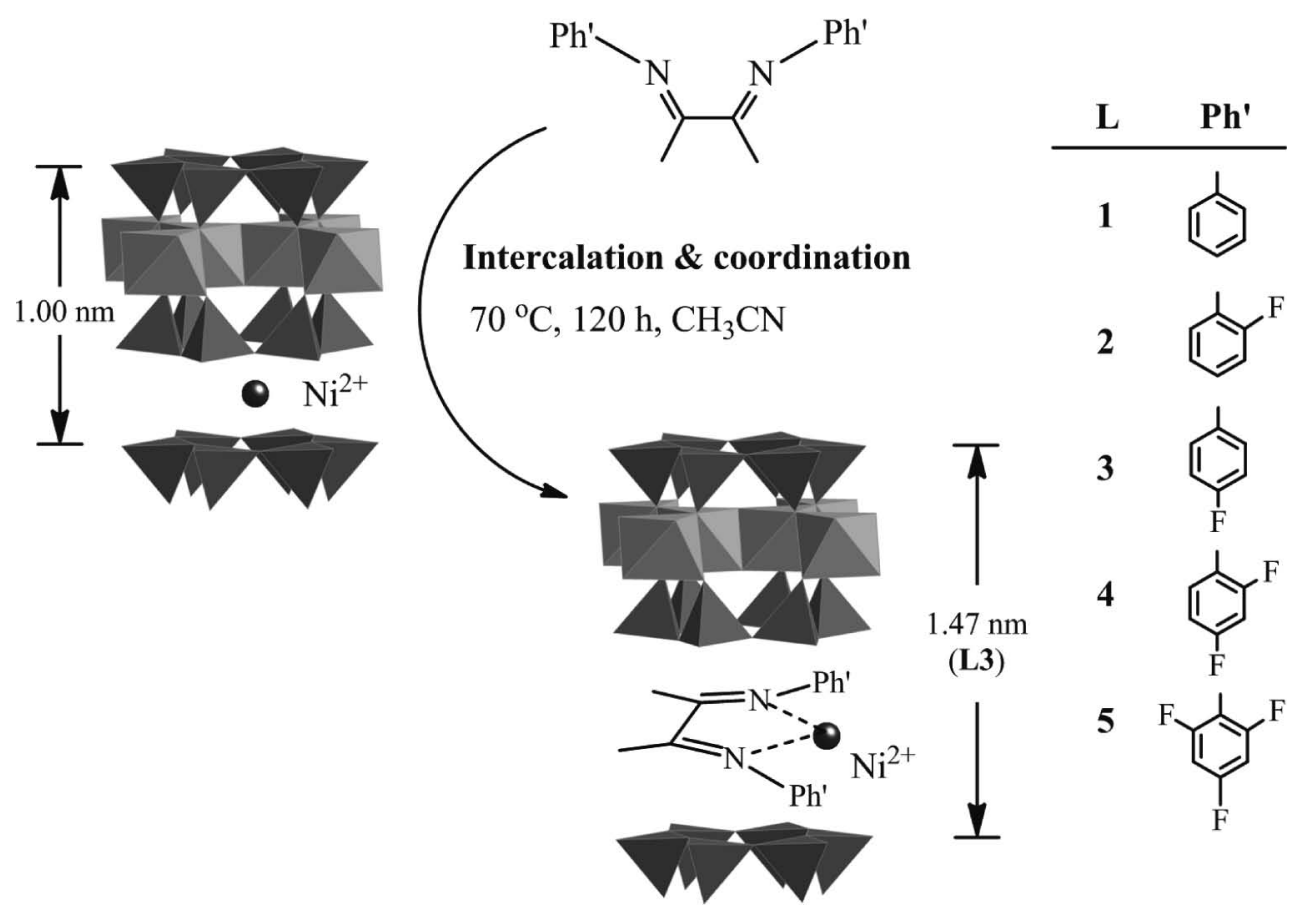

Fig. 1 Proposed Feature of $\alpha$-Diiminenickel Complex Immobilized in Fluorotetrasilicic Mica Interlayer

nickel-based catalysts ${ }^{56)}$. However, the modification significantly decreased the catalytic activity, and a considerable amount of undesirable polyethylene wax having a low melting temperature was still formed with the oligomers as a critical problem of these catalysts after the ligand modification.

Based on these results, it is necessary to improve the catalyst performances, and the aim of this study is to increase the catalytic activity of the nickel-based catalysts by applying the fluorine-modified $\alpha$-diimine ligand to the immobilized nickel-based catalysts.

\section{Experimental}

Toluene, $n$-hexane, and other solvents were obtained from Kanto Chemical Co., Inc., and were dehydrated by MS-13x dried at $400{ }^{\circ} \mathrm{C}$. They were degassed by $\mathrm{N}_{2}$ bubbling and then stored under an inert gas atmosphere. The chemicals used for the ligand preparation were purchased from Tokyo Chemical Industry Co., Ltd. Fluorotetrasilicic mica was supplied from COOP Chemical Co., Ltd. The procatalysts were handled by a standard Schlenk technique under a $\mathrm{N}_{2}$ atmosphere. The procatalysts used in this study are summarized in Fig. 1.

\section{1. Ligand Synthesis}

The ligands L1-5 were prepared according to the method described in the literature with a slight modification $^{8), 9), 56)}$. The typical procedure of the ligand synthesis is indicated below. Methanol $(6 \mathrm{~mL}), 2,3-$ butanedione $(0.287 \mathrm{~g}, 3.33 \mathrm{mmol})$, 2,4-difluoroaniline
$(1.089 \mathrm{~g}, 8.42 \mathrm{mmol})$, and a few drops of glacial acetic acid were successively added to a $\mathrm{N}_{2}$-purged $100-\mathrm{mL}$ flask. The reaction was performed at ambient temperature for $96 \mathrm{~h}$ with stirring. The target ligand gradually precipitated with time. After the reaction, the crude ligand was washed with a small amount of dehydrated methanol. The pure ligand was obtained by drying the washed one at ambient temperature under reduced pressure. Instrumental analyses by ${ }^{1} \mathrm{H}-\mathrm{NMR}$ (Bruker Avance III, resonance frequency for ${ }^{1} \mathrm{H}=300 \mathrm{MHz}$ ) and double-focused sector MS (JEOL, AM 500, direct inlet and EI method) were used for the identification of the prepared ligands. The data of the prepared ligands L2-5 are displayed below.

L2:

Yield $=14 \%$

${ }^{1} \mathrm{H}-\mathrm{NMR}: \delta 2.18(6 \mathrm{H}, \mathrm{s},-\mathrm{N}=\mathrm{C}-\mathrm{Me}), \delta$ 6.85-6.91 $(4 \mathrm{H}, \mathrm{m}, \mathrm{Ph}), \delta$ 7.08-7.13 (6H, m, Ph); MS (DI) m/e $=272($ parent ion $), 136\left(2-\mathrm{FPh}^{-} \mathrm{N}=\mathrm{C}^{+} \mathrm{Me}\right), 95$ $\left(\mathrm{FPh}^{+}\right)$.

L3:

Yield $=38 \%$

${ }^{1} \mathrm{H}-\mathrm{NMR}: \delta 2.15(6 \mathrm{H}, \mathrm{s},-\mathrm{N}=\mathrm{C}-\mathrm{Me}), \delta 6.73-6.78$ (2H, dd, 6-H-Ph), $\delta 7.07$ (2H, dd, 5-H-Ph); MS (DI) $\mathrm{m} / \mathrm{e}=272$ (parent ion), $136\left(4-\mathrm{FPh}-\mathrm{N}=\mathrm{C}^{+} \mathrm{Me}\right), 95$ $\left(\mathrm{FPh}^{+}\right)$.

L4:

Yield $=33 \%$

${ }^{1} \mathrm{H}-\mathrm{NMR}: \delta 2.16(6 \mathrm{H}, \mathrm{s},-\mathrm{N}=\mathrm{C}-\mathrm{Me}), \delta$ 6.81-6.92 $(6 \mathrm{H}, \mathrm{m}, \mathrm{Ph}) ; \mathrm{MS}$ (DI) $\mathrm{m} / \mathrm{e}=308$ (parent ion), 154 $\left(2,4-\mathrm{F}_{2} \mathrm{Ph}-\mathrm{N}=\mathrm{C}^{+} \mathrm{Me}\right), 95\left(\mathrm{~F}_{2} \mathrm{Ph}^{+}\right)$. 
Table 1 Physicochemical Properties of $\mathrm{Ni}^{2+}-$ mica $^{\text {a) }}$

\begin{tabular}{|c|c|c|c|c|c|c|c|c|c|c|c|c|}
\hline \multirow{2}{*}{$\begin{array}{c}\text { Clay } \\
\text { mineral }\end{array}$} & \multicolumn{9}{|c|}{ Composition [wt $\%$ ] } & \multirow{2}{*}{$\begin{array}{l}\text { Amount } \\
\text { of } \mathrm{Ni}^{2+} \text { ) }\end{array}$} & \multirow{2}{*}{$\begin{array}{c}\text { Exchange } \\
{[\%]}\end{array}$} & \multirow{2}{*}{$\mathrm{BET} \mathrm{SA}^{\mathrm{c})}$} \\
\hline & $\mathrm{Na}_{2} \mathrm{O}$ & $\mathrm{MgO}$ & $\mathrm{Al}_{2} \mathrm{O}_{3}$ & $\mathrm{SiO}_{2}$ & $\mathrm{~S}$ & $\mathrm{~K}_{2} \mathrm{O}$ & $\mathrm{CaO}$ & $\mathrm{Fe}_{2} \mathrm{O}_{3}$ & $\mathrm{NiO}$ & & & \\
\hline $\mathrm{Na}^{+}$-mica & 6.4 & 31.1 & 0.6 & 59.3 & - & - & - & $<0.1$ & - & - & - & 3.3 \\
\hline $\mathrm{Ni}^{2+}$-mica & 1.9 & 31.2 & 0.4 & 58.0 & - & - & $<0.1$ & $<0.1$ & 6.0 & 0.805 & $95^{\mathrm{d})}$ & 3.9 \\
\hline
\end{tabular}

a) The amount of fluorine was fixed at the constant value $(2.48 \mathrm{wt} \%)$ described in the supplier specification, because fluorine was not detectable by this technique.

b) Amount of exchanged $\mathrm{Ni}^{2+}$ ions $=\mu \mathrm{mol} \mathrm{g}{ }^{-1}$. ${ }^{\text {c) }}$ BET surface area $=\mathrm{m}^{2} \mathrm{~g}^{-1}$.

d) Determined by the following equation.

$M_{\mathrm{Ni}} /\left[0.5\left(M_{\mathrm{Na}}^{\mathrm{b}}-M_{\mathrm{Na}}^{\mathrm{a}}\right)+1.5\left(M_{\mathrm{Al}}^{\mathrm{b}}-M_{\mathrm{Al}}^{\mathrm{a}}\right)\right]$

$M_{\mathrm{Ni}}=$ mole of $\mathrm{Ni}^{2+}$ ions (amount of $\mathrm{Ni}^{2+}$ ions). $M_{\mathrm{Na}}{ }^{\mathrm{b}}$ and $M_{\mathrm{Al}}^{\mathrm{b}}=$ moles of $\mathrm{Na}^{+}$and $\mathrm{Al}^{3+}$ ions before ion-exchange reaction.

$M_{\mathrm{Na}}{ }^{\mathrm{a}}$ and $M_{\mathrm{Al}}^{\mathrm{a}}=$ moles of $\mathrm{Na}^{+}$and $\mathrm{Al}^{3+}$ ions after ion-exchange reaction.

L5:

Yield $=12 \%$

${ }^{1} \mathrm{H}-\mathrm{NMR}: \delta 2.20(6 \mathrm{H}, \mathrm{s},-\mathrm{N}=\mathrm{C}-\mathrm{Me}), \delta 6.74-6.80$

(4H, d, Ph); MS (DI) m/e = 344 (parent ion), 172

$\left(2,4,6-\mathrm{F}_{3} \mathrm{Ph}-\mathrm{N}=\mathrm{C}^{+} \mathrm{Me}\right), 145\left(2,4,6-\mathrm{F}_{3} \mathrm{Ph}-\mathrm{N}^{+}\right), 131$ $\left(\mathrm{F}_{3} \mathrm{Ph}^{+}\right)$.

\section{2. Procatalyst Preparation}

Nickel ion-exchanged fluorotetrasilicic mica $\left(\mathrm{Ni}^{2+}\right.$ mica) was prepared according to a previous paper ${ }^{55}$. The physicochemical properties of the prepared $\mathrm{Ni}^{2+}$ mica are summarized in Table 1. To a $20-\mathrm{mL}$ Schlenk flask, the prepared $\mathrm{Ni}^{2+} /$ mica $(0.25 \mathrm{~g})$ and the acetonitrile solution of the appropriate ligand ( $850 \mathrm{mmol}$-ligand for $1 \mathrm{~g} \mathrm{Ni}^{2+}$-mica) were added under a nitrogen atmosphere, and then allowed to react at $70{ }^{\circ} \mathrm{C}$ for $120 \mathrm{~h}$. After the reaction, the solid part settled out and then the clear solution was carefully removed by a syringe. Acetonitrile, toluene, and $n$ hexane were used for successively washing the solid part. The procatalysts $\mathbf{L 1 - 6} / \mathrm{Ni}^{2+}$-mica were obtained by drying the solid at ambient temperature for $4 \mathrm{~h}$ under reduced pressure.

\section{3. Ethylene Oligomerization}

An autoclave (120-mL volume) equipped with a magnetic stirrer, a pressure gauge, and valves to introduce the solvent, procatalyst, co-catalyst, and ethylene was used for the ethylene oligomerization. Solvent (including exactly weighed $0.1-\mathrm{mL} n$-tridecane as an internal standard), the procatalysts, and an activator (TEA or TIBA) were successively added to the autoclave, and the oligomerization reaction was performed at $40-80{ }^{\circ} \mathrm{C}$ and $0.7 \mathrm{MPa}$ with a continuous supply of ethylene. After the oligomerization, $1.0 \mathrm{~mL}$ of a gas sample was extracted from the gas-phase in the autoclave and analyzed by a thermal conductivity detector (TCD) gas chromatograph to determine the amount of $\mathrm{C}_{4}$ products in the gas-phase. The liquid phase was cooled to $0{ }^{\circ} \mathrm{C}$ in an ice bath and then the produced oligomers $\left(\mathrm{C}_{6}-\mathrm{C}_{22}\right)$ were quantitatively determined by a gas chromatograph equipped with an hydrogen-flame ionization detector (FID) and a capillary column (methyl silicone, $0.25-\mathrm{mm}$ internal diameter, $60 \mathrm{~m}$ ). The ethylene consumption rate during the oligomerization was measured using a mass-flow meter connected to the ethylene supply line. The activities in all the runs were determined by the total amount of the ethylene consumption.

\section{4. Characterization of Procatalyst}

The compositions of $\mathrm{Na}^{+}$- and $\mathrm{Ni}^{2+}$-mica were determined by X-ray fluorescence (XRF) analysis (PANalytical B.V., PW2400). A mixture of the mica and cellulose (total $=0.250 \mathrm{~g}$, oil shale $:$ cellulose $=1: 1$ by weight) was molded into a wafer having a $10-\mathrm{mm}$ diameter as a specimen for the XRF analysis.

The procatalyst and a small amount of dry liquidparaffin were mixed under an inert gas atmosphere, and the obtained paste was placed on a glass specimen holder. The holder was covered with a polyester film to avoid exposure to air. The X-ray diffraction (XRD) analysis was performed using a Rigaku Ultima III Spectrometer (operating conditions; $\mathrm{X}$-ray $=\mathrm{Cu} K \alpha$ line $(\lambda=$ $0.15406 \mathrm{~nm})$, scan rate $=1.0 \mathrm{deg} \cdot \mathrm{min}^{-1}$, scan angle $(2 q)$ $=3-15$ deg., sampling step $=0.02$ deg., voltage and current $=40 \mathrm{kV}$ and $40 \mathrm{~mA}$ ). The basal spacing of the procatalyst was determined from the (001) diffraction peak.

Thermogravimetry (TG) and a differential thermal analysis (DTA) were performed using a Shimazu DTG60 thermal analyzer. The procatalyst $(5-7 \mathrm{mg})$ was weighed in a platinum sample pan in a glove box under a nitrogen atmosphere, and then placed in the TG-DTA apparatus. The operating conditions are as follows: heating rate $=10{ }^{\circ} \mathrm{C} \mathrm{min}^{-1}$, temperature range $=$ r.t. to $700{ }^{\circ} \mathrm{C}$, under a dry air atmosphere $\left(50 \mathrm{~mL} \mathrm{~min}^{-1}\right)$.

\section{Results and Discussion}

\section{1. Ethylene Oligomerization Using $\mathbf{L 1}-5 / \mathrm{Ni}^{2+}$ - mica Procatalysts}

The results of the ethylene oligomerization using the heterogeneous catalysts (procatalysts, $\mathbf{L 1 - 5} / \mathrm{Ni}^{2+}$-mica) based on $\alpha$-diimine nickel complexes bearing the L1-5 ligands are summarized in Table 2. The results of the ethylene oligomerization using the procatalyst $\mathbf{L} \mathbf{1} / \mathrm{Ni}^{2+}$ mica have already been reported in a previous paper ${ }^{55)}$. The procatalysts $\left(\mathbf{L} 2-4 / \mathrm{Ni}^{2+}\right.$-mica) based on the com- 
Table 2 Ethylene Oligomerization Using Heterogeneous Catalysts Prepared from F-substituted $\alpha$-Diimine Ligand and $\mathrm{Ni}^{2+}$-mica

\begin{tabular}{|c|c|c|c|c|c|c|c|c|}
\hline \multirow{2}{*}{ Run } & \multirow{2}{*}{$\mathbf{L}$} & \multirow{2}{*}{ Activator } & \multirow{2}{*}{$\begin{array}{c}\text { Activity } \\
{\left[\mathrm{g}_{-} \mathrm{C}_{2} \mathrm{~g} \text {-cat }^{-1} \mathrm{~h}^{-1}\right]}\end{array}$} & \multicolumn{2}{|c|}{ Product $^{\text {b) }}[w t \%]$} & \multirow{2}{*}{$S_{\alpha}^{c)}[\%]$} & \multirow{2}{*}{$\alpha^{\mathrm{d})}$} & \multirow{2}{*}{$T_{\mathrm{m}}^{\mathrm{e})}\left[{ }^{\circ} \mathrm{C}\right]$} \\
\hline & & & & Solid & $\mathrm{C}_{4}-\mathrm{C}_{22}$ & & & \\
\hline 1 & 1 & TEA & 73 & 4.1 & 58.6 & 96.4 & 0.59 & NA \\
\hline 2 & 2 & TEA & 248 & 3.9 & 59.0 & 97.6 & 0.56 & $93,109,125$ \\
\hline 3 & 2 & TIBA & 208 & 4.9 & 63.6 & 96.5 & 0.57 & $91,105,125$ \\
\hline 4 & 3 & TEA & 170 & 8.1 & 53.5 & 97.6 & 0.65 & $91,107,125$ \\
\hline 5 & 3 & TIBA & 133 & 2.9 & 58.5 & 95.7 & 0.57 & 107,126 \\
\hline 6 & 4 & TEA & 347 & 6.5 & 70.0 & 97.0 & 0.55 & $89,108,125$ \\
\hline 7 & 4 & TIBA & 256 & 7.7 & 70.3 & 94.1 & 0.58 & $89,108,125$ \\
\hline 8 & 5 & TEA & 18 & 6.9 & 71.1 & $\sim 100$ & 0.53 & NA \\
\hline 9 & 5 & TIBA & 26 & 7.3 & 102 & $\sim 100$ & 0.55 & $91,107,123$ \\
\hline
\end{tabular}

a) Reaction conditions; temperature $=60^{\circ} \mathrm{C}$, ethylene pressure $=0.7 \mathrm{MPa}$ (gauge), activator $=1.02 \mathrm{mmol}$, cat. weight $=4.0 \mathrm{mg}$, solvent $=n$-heptane $(50 \mathrm{~mL})$.

b) "Solid" indicates the amount of the solid part recovered by filtration of the reaction mixture. " $\mathrm{C}_{4}-\mathrm{C}_{22}$ " represents the amount of hydrocarbons having the carbon number 4-22.

c) Selectivity to $\alpha$-olefins (average value of each selectivity calculated for $\mathrm{C}_{10}-\mathrm{C}_{18}$ products).

d) $\alpha$ (probability of chain propagation $)=\left(\right.$ moles of $\left.\mathrm{C}_{n+2}\right) /\left(\right.$ moles of $\left.\mathrm{C}_{n}\right) . \quad \alpha$ was indicated as the average values of these calculated for $n=6-16$.

e) Melting point of solid product. Italic values indicate shoulder peak. NA = not analyzed.

plexes bearing the $\alpha$-diimine ligands containing phenyl groups substituted by mono- or di-fluorine atoms showed a much higher activity for the ethylene oligomerization compared to the procatalyst $\left(\mathbf{L} \mathbf{1} / \mathrm{Ni}^{2+}\right.$-mica) based on the complex bearing no fluorine-substituted ligand L1. In contrast, an extremely low activity was observed during the ethylene oligomerization using the $\mathbf{L 5} / \mathrm{Ni}^{2+}$-mica procatalyst having the ligand containing 2,4,6-trifluorophenyl groups. The low activity of $\mathbf{~ L 5 / ~}$ $\mathrm{Ni}^{2+}$-mica can be explained by the following speculation. The electron withdrawing groups such as fluorine-substituted phenyl groups increase the positive net charge of the nickel center. Although the catalytic activity increases with increasing its positive charge, the nickel center having the excess positive-charge interacts strongly with ethylene, and the strong interaction prevents the insertion of ethylene into the metalalkyl bond of the active species.

The highest activity was obtained by the $\mathbf{L} 4 / \mathrm{Ni}^{2+}$ mica procatalysts having 2,4-difluorophenyl groups. Although the $\mathbf{L 2 - 4} / \mathrm{Ni}^{2+}$-mica procatalysts were readily activated by a conventional alkylaluminum compound, the activities of the procatalysts combined with TEA (Runs 2, 4, and 6) was slightly higher than those combined with TIBA (Runs 3, 5, and 7). The activation of the procatalyst by TEA was more readily than that by TIBA due to the higher Lewis acidity of TEA.

The synthesis of the nickel complex bearing a mono fluorine-substituted ligand (o-, $m$-, or $p$-fluorophenyl group on the nitrogen atoms) and its use for the homogeneous ethylene oligomerization combined with MAO were investigated by Helldörfer $e t$ al. ${ }^{9}$. They reported that the nickel complex having $p$-fluorophenyl groups showed a much higher activity than those of other complexes. Moreover, they also reported that the oligomerization using the complexes bearing the ligand

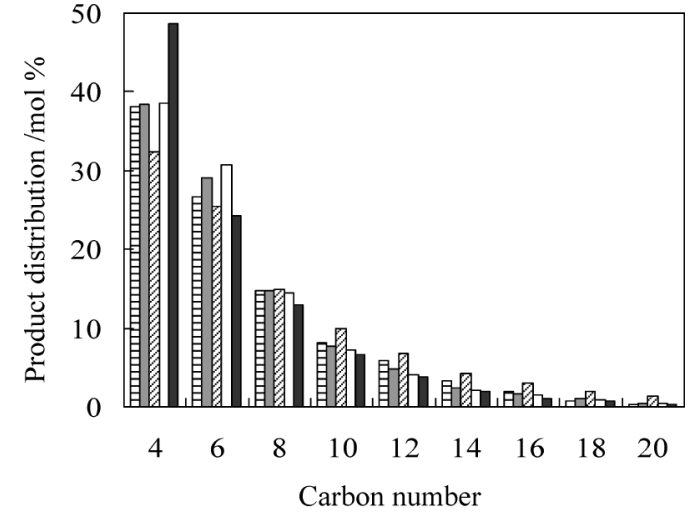

目 L1 , $\square \mathbf{L 2}$, 思3, $\square \mathbf{L 4}, \square \mathbf{L 5}$

Reaction conditions are the same as listed in Table 2.

Fig. 2 Distribution of Oligomers Obtained Using L1-5/ $/ \mathrm{Ni}^{2+}$-mica Procatalysts in the Presence of TEA

containing the fluorophenyl group resulted in the formation of only ethylene oligomers, and the polyethylene (solid product) amount was not more than $1 \mathrm{wt} \%$ at $60{ }^{\circ} \mathrm{C}$ under 10 bar $\left(1 \mathrm{bar}=1 \times 10^{5} \mathrm{~Pa}\right)$. The SchulzFlory constants $\alpha$ obtained in all the runs were within 0.65-0.68. The $\alpha$ value is defined as the formula $R_{\mathrm{p}} /$ $\left(R_{\mathrm{p}}+R_{\mathrm{t}}\right)$, where $R_{\mathrm{p}}$ and $R_{\mathrm{t}}$ are the rates of the propagation and the chain transfer reaction, respectively.

On the contrary, the $\mathbf{L} \mathbf{2}-\mathbf{4} / \mathrm{Ni}^{2+}$-mica catalysts afforded 2.9-8.1 wt \% of polyethylene in addition to ethylene oligomers, and the $\alpha$ value (0.55-0.65) were slightly lower than those obtained by the homogeneous catalysts. The oligomer distributions are shown in Fig. 2. In all the runs, the oligomer distributions were in agreement with the Schultz-Flory equation, but considerable amounts of polyethylene (Table 2, "Solid") were produced. The results suggested that the active sites for 
the polyethylene formation were different from those for the oligomer formation, because the amount of the formed polyethylene was much higher than that (not more than $0.1 \mathrm{wt} \%$ ) estimated based on the obtained $\alpha$ value (0.7) and the assumed molecular weight of the polyethylene $\left(M_{\mathrm{n}}>1000 \mathrm{~g} \mathrm{~mol}^{-1}\right)$.

Figure 3 indicates the profiles of the ethylene consumption during the oligomerization using the $\mathbf{L 1 - 5} / \mathrm{Ni}^{2+}$ mica. In the initial stage of the oligomerization, the ethylene consumption was occasionally observed, which was caused by the ethylene absorption into the solvent. When $\mathbf{L} \mathbf{1} / \mathrm{Ni}^{2+}$-mica procatalyst was used for the oligomerization, the induction period was observed for approximately $30 \mathrm{~min}$, but the period was shortened to within 20 min by replacing $\mathbf{L} \mathbf{1}$ with the fluorinecontaining L2-4 ligand. Additionally, the maximum rate of ethylene consumption dramatically increased and the highest rate was obtained using the procatalyst

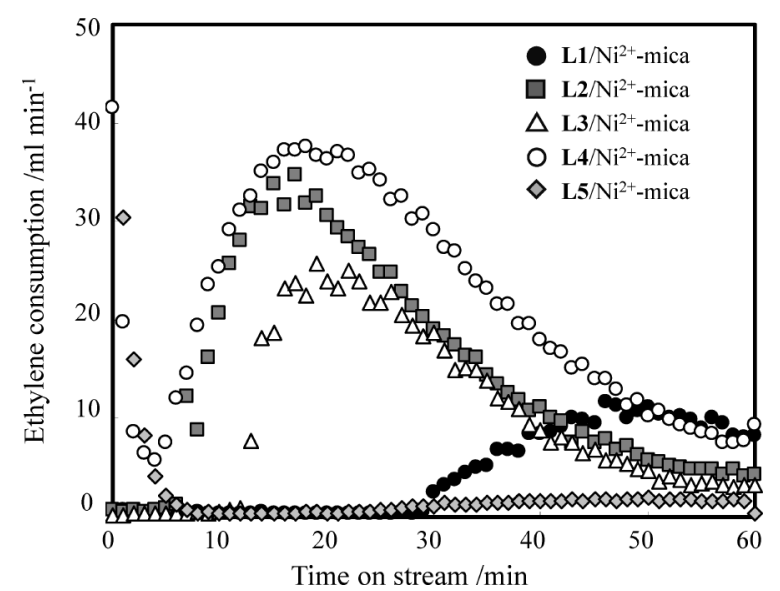

Reaction conditions are the same as listed in Table 2.

Fig. 3 Profiles of Ethylene Consumption during Ethylene oligomerization Using L1-5/ $\mathrm{Ni}^{2+}$-mica Procatalysts in the Presence of TEA consisting of the $\mathrm{Ni}^{2+}$-mica and the $\mathbf{L} \mathbf{4}$ ligand having 2,4-difluorophenyl groups.

\section{2. Ethylene Oligomerization Using $\mathrm{L} 4 / \mathrm{Ni}^{2+}$-mica Procatalyst}

Table 3 indicates the results of the ethylene oligomerization at $40-70{ }^{\circ} \mathrm{C}$ using the most active $\mathbf{L 4} / \mathrm{Ni}^{2+}$ mica procatalyst in the presence of $\mathrm{R}_{3} \mathrm{Al}$. The activity obtained by the catalysts combined with the $\mathbf{L} \mathbf{4} / \mathrm{Ni}^{2+}$ mica and TEA was similar to that obtained by the catalysts combined with $\mathbf{L} 4 / \mathrm{Ni}^{2+}$-mica and TIBA. The total ethylene consumption increased when the temperature was raised from 40 to $50-60{ }^{\circ} \mathrm{C}$, however, at $70{ }^{\circ} \mathrm{C}$, the consumption clearly decreased due to the decomposition of the active species.

The higher reaction temperature favored the formation of the $\mathrm{C}_{4}-\mathrm{C}_{22}$ oligomers with the decreasing solid product, because the chain-transfer reaction was relatively promoted with the increasing temperature compared to the propagation reaction. The $\alpha$ values also decreased from 0.65 to 0.51 in the oligomerization using TEA and from 0.63 to 0.50 in those using TIBA with the increasing temperature. Meanwhile, the selectivity to $\alpha$-olefins $\left(S_{\alpha}\right)$ gradually decreased with the increasing temperature, and this decrease was caused by the copolymerization between the produced $\alpha$-olefins and ethylene. Moreover, it is well-known that the polymerization of ethylene using $\alpha$-diimine nickel complexes affords a branch polyethylene by "chain walking," which increased with the increasing reaction temperature ${ }^{57)}$. The increase in the "chain walking" resulted in the increasing mole fraction of branch oligomers.

Figure 4 indicates the oligomer distribution obtained using the $\mathbf{L} 4 / \mathrm{Ni}^{2+}$-mica procatalyst combined with TEA. At the higher reaction temperature, the amount of $\mathrm{C}_{4}$ and $\mathrm{C}_{6}$ oligomers increased, however, on the contrary, the amount of $\mathrm{C}_{12}-\mathrm{C}_{22}$ oligomers clearly decreased. The chain transfer reaction is dominant at the higher

Table 3 Ethylene Oligomerization Using $\mathbf{L} \mathbf{4} / \mathrm{Ni}^{2+}$-mica Procatalyst

\begin{tabular}{|c|c|c|c|c|c|c|c|c|}
\hline \multirow{2}{*}{ Run } & \multirow{2}{*}{$T_{\mathrm{p}}\left[{ }^{\circ} \mathrm{C}\right]$} & \multirow{2}{*}{ Activator } & \multirow{2}{*}{ 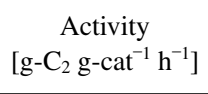 } & \multicolumn{2}{|c|}{ Product $^{\text {b) }}[w t \%]$} & \multirow{2}{*}{$S_{\alpha}{ }^{c)}[\%]$} & \multirow{2}{*}{$\alpha^{\mathrm{d})}$} & \multirow{2}{*}{$T_{\mathrm{m}}^{\mathrm{e})}\left[{ }^{\circ} \mathrm{C}\right]$} \\
\hline & & & & Solid & $\mathrm{C}_{4}-\mathrm{C}_{22}$ & & & \\
\hline 10 & 40 & TEA & 274 & 21.0 & 49.9 & 99.5 & 0.65 & 104,127 \\
\hline 11 & 50 & TEA & 302 & 14.9 & 60.7 & 97.1 & 0.63 & $90,107,128$ \\
\hline 6 & 60 & TEA & 347 & 6.5 & 70.0 & 97.0 & 0.55 & $89,108,125$ \\
\hline 12 & 70 & TEA & 163 & 0.3 & 72.2 & 92.1 & 0.51 & NA \\
\hline 13 & 40 & TIBA & 236 & 23.0 & 51.7 & 99.6 & 0.63 & $87,107,126$ \\
\hline 14 & 50 & TIBA & 420 & 14.6 & 60.7 & 95.0 & 0.62 & $86,106,125$ \\
\hline 7 & 60 & TIBA & 256 & 7.7 & 70.3 & 94.1 & 0.58 & $89,108,125$ \\
\hline 15 & 70 & TIBA & 192 & 0.7 & 80.4 & 91.8 & 0.50 & NA \\
\hline
\end{tabular}

a) Reaction conditions; ethylene pressure $=0.7 \mathrm{MPa}$ (gauge), activator $=1.02 \mathrm{mmol}$, cat. weight $=4.0 \mathrm{mg}$, solvent $=n$-heptane $(50 \mathrm{~mL})$.

b) "Solid" indicates the amount of the solid part recovered by filtration of the reaction mixture. "C $\mathrm{C}_{4}-\mathrm{C}_{22}$ " represents the amount of hydrocarbons having the carbon number 4-22.

c) Selectivity to $\alpha$-olefins (average value of each selectivity calculated for $\mathrm{C}_{10}-\mathrm{C}_{18}$ products).

d) $\alpha$ (probability of chain propagation $)=\left(\right.$ moles of $\left.\mathrm{C}_{n+2}\right) /\left(\right.$ moles of $\left.\mathrm{C}_{n}\right) . \quad \alpha$ was indicated as the average values of these calculated for $n$ $=6-16$.

e) Melting point of solid product. Italic values indicate shoulder peak. NA $=$ not analyzed. 


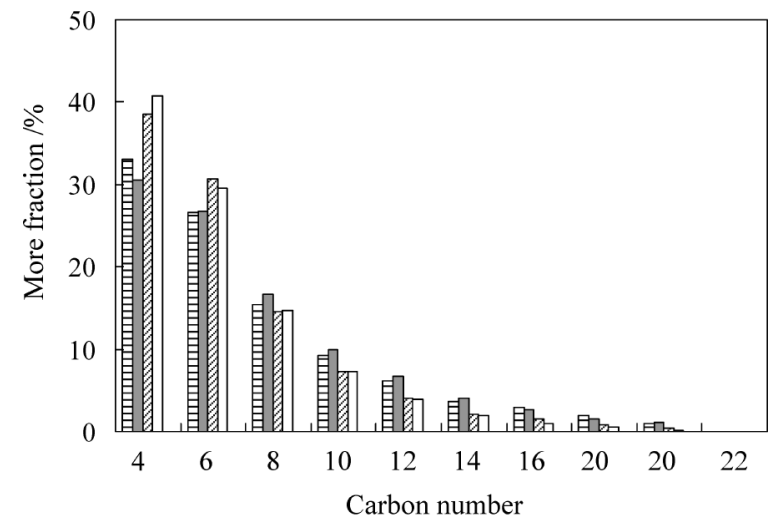

$40{ }^{\circ} \mathrm{C}, \square 50{ }^{\circ} \mathrm{C}, \square 60^{\circ} \mathrm{C}, \square 70{ }^{\circ} \mathrm{C}$

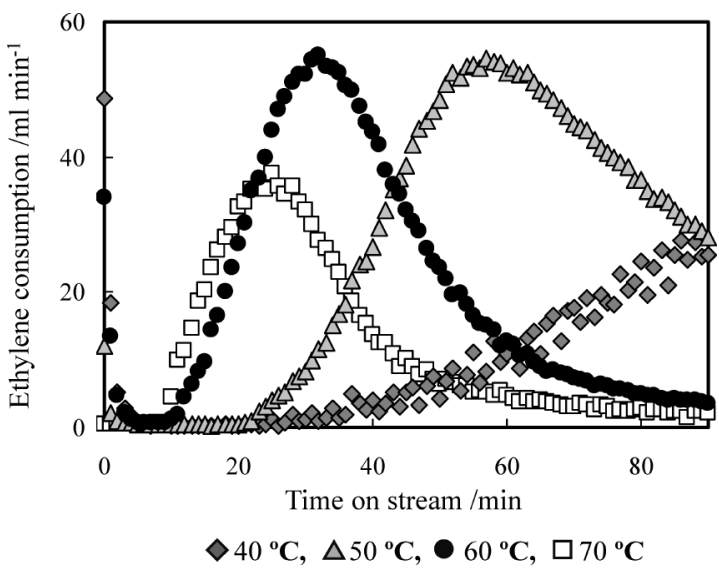

Reaction conditions are the same as listed in Table 3.

Fig. 6 Profiles of Ethylene Consumption during Ethylene Oligomerization Using $\mathbf{L} 4 / \mathrm{Ni}^{2+}$-mica Procatalyst in the Presence of TIBA

rate was obtained at $60{ }^{\circ} \mathrm{C}$. The low consumption rate at $70{ }^{\circ} \mathrm{C}$ is due to the deactivation of the catalyst, because the deactivation markedly occurred with the increasing reaction temperature.

The ethylene consumption profiles using the $\mathbf{L} \mathbf{4} / \mathrm{Ni}^{2+}$ mica in the presence of TIBA are summarized in Fig. 6. Although the activities (calculated on the basis of the total ethylene consumption) obtained using TIBA were nearly equal to those obtained using TEA, the consumption profiles were clearly different; a short induction period was observed even at $60{ }^{\circ} \mathrm{C}$ during the oligomerization using TIBA, and a longer time was needed until the rate attained a maximum. The important role of $\mathrm{R}_{3} \mathrm{Al}$ is generally understood to be an alkylating agent of a metal complex in the homogeneous system, and the alkylation step is also required for the activation of the complex in this catalyst system. The reactivity of TIBA is considered to be much less than that of TEA, therefore, the low reactivity of TIBA is one of the reasons for the long activation time. Moreover, the characteristic structure of the clay mineralbased catalysts might affect the induction period. A high catalytic activity was readily obtained by the clay mineral-based catalysts when they were activated by $\mathrm{R}_{3} \mathrm{Al}$ as well as MAO, suggesting that $\mathrm{R}_{3} \mathrm{Al}$ took part in the formation of the active species by adsorption on the clay mineral surface. The relationship between the structure and the catalytic behavior of the procatalyst is discussed in Section 3. 3.

\section{3. Characterization of the Procatalyst by XRD Measurement}

The XRD profiles of the prepared procatalysts, the dried $\mathrm{Ni}^{2+}$-mica, and that treated with only $\mathrm{CH}_{3} \mathrm{CN}$ are summarized in Fig. 7. The basal spacing of the dried $\mathrm{Ni}^{2+}$-mica was $1.0 \mathrm{~nm}$ corresponding to the thickness of a mica sheet. When the dried $\mathrm{Ni}^{2+}$-mica was treated 


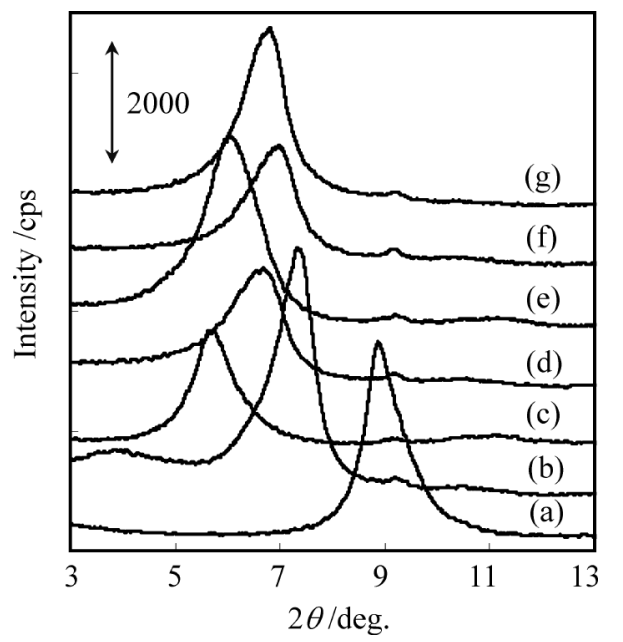

Spectra (a) and (b) indicate $\mathrm{Ni}^{2+}$-mica after drying at $200{ }^{\circ} \mathrm{C}$ (a) and treating it with only $\mathrm{CH}_{3} \mathrm{CN}$ (b), respectively. Spectra (c-g) correspond to the procatalysts prepared with $\mathrm{Ni}^{2+}$-mica and $\mathbf{L 1}$ (c), $\mathbf{L 2}(\mathrm{d})$, $\mathbf{L 3}$ (e), $\mathbf{L 4}$ (f), and $\mathbf{L 5}$ (g) in $\mathrm{CH}_{3} \mathrm{CN}$. The measurement of samples (b-g) was performed after drying at $110{ }^{\circ} \mathrm{C}$.

Fig. 7 XRD Profiles of the Procatalysts and Related Materials

in $\mathrm{CH}_{3} \mathrm{CN}$, the distance between adjacent layers expanded to $1.21 \mathrm{~nm}$, indicating that $\mathrm{CH}_{3} \mathrm{CN}$ was intercalated into the mica interlayer. In all the procatalysts, expansion of the basal spacing was observed, but each value of the basal spacing was clearly different. The $\mathbf{L 1}$ and $\mathbf{L 3} / \mathrm{Ni}^{2+}$-mica procatalysts showed a large expansion of the spacing, and these values were $1.54 \mathrm{~nm}$ and $1.47 \mathrm{~nm}$, respectively. In contrast, the basal spacings of the $\mathbf{L} \mathbf{2}, \mathbf{L 3}$, and $\mathbf{L 4} / \mathrm{Ni}^{2+}$-mica procatalysts were relatively small at $1.32,1.27$, and $1.30 \mathrm{~nm}$, respectively. The difference between the basal spacings was caused by the different conformations of the formed complexes on the inside of the interlayer. Moreover, the activity order of the procatalysts did not coincide with that of the distance between adjacent layers. For example, the $\mathbf{L} 4 / \mathrm{Ni}^{2+}$-mica procatalyst showed the highest activity among the used procatalysts, but the basal spacing was relatively small. At this stage, we do not understand the reason for the difference in the basal spacing due to the lack of information about the structure of the formed complex, however, it seems that the basal spacing and the peak intensity were highly relevant to not only the amount of the formed complexes, but also the three-dimensional structure of the complex located in the interlayer.

Figure 8 indicates the profiles of the TG-DTA analysis for (b) $\mathrm{Ni}^{2+}$-mica treated with only $\mathrm{CH}_{3} \mathrm{CN}$ and (a) the procatalyst $\left(\mathbf{L} 4 / \mathrm{Ni}^{2+}\right.$-mica). In both profiles (a) and (b), the weight loss by the endothermic reaction was clearly observed around $40{ }^{\circ} \mathrm{C}$, and that loss was 3.5-3.7 wt $\%$ of the total weight. This reaction could be attributed to the elimination of the physically adsorbed $\mathrm{CH}_{3} \mathrm{CN}$ from the interlayer space. After the

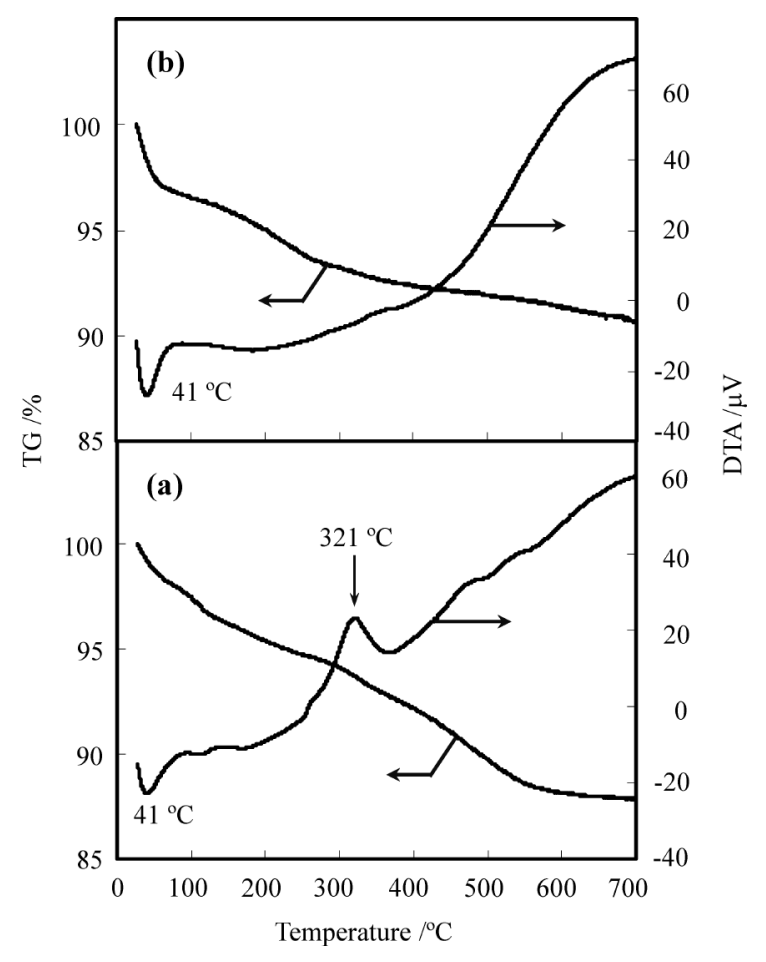

Profiles (a) and (b) indicate $\mathrm{Ni}^{2+}$-mica treated with only $\mathrm{CH}_{3} \mathrm{CN}$ and the $\mathbf{L} \mathbf{4} / \mathrm{Ni}^{2+}$-mica procatalyst, respectively (sample weight: (a) $6.618 \mathrm{mg}$, (b) $4.743 \mathrm{mg}$ ).

Fig. 8 Thermal Analysis Results of the $\mathbf{L} \mathbf{4} / \mathrm{Ni}^{2+}$-mica Procatalyst

elimination of $\mathrm{CH}_{3} \mathrm{CN}$, the weight loss continued in both (a) and (b). The weight loss of the profile (b) in the temperature range of $150-250{ }^{\circ} \mathrm{C}$ was due to the elimination of the $\mathrm{CH}_{3} \mathrm{CN}$ coordinated to the metal ions, because no similar weight decrease was observed in the same temperature range in the TG profile of the $\mathrm{Ni}^{2+}$-mica dried at $200{ }^{\circ} \mathrm{C}$. Meanwhile, in profile (a), the exothermic reaction was clearly observed at $320{ }^{\circ} \mathrm{C}$, indicating that the metal complex placed in the interlayer space had decomposed. The weight gradually decreased over $400{ }^{\circ} \mathrm{C}$ with small peaks due to the exothermic reactions $\left(474{ }^{\circ} \mathrm{C}\right.$ and $536{ }^{\circ} \mathrm{C}$ ). The total weight loss in the temperature range of $150-700{ }^{\circ} \mathrm{C}$ was $8.4 \mathrm{wt} \%$ $(0.558 \mathrm{mg})$, and this value corresponded to $187 \mathrm{mmol}$ g-cat ${ }^{-1}$ of the L4Ni(vacant) ${ }_{2}$ complex (molar mass $=$ $449 \mathrm{~g} \mathrm{~mol}^{-1}$ ). The "vacant" term in the chemical formula means the vacant site of the complex, and now we consider that an oxygen atom of the mica sheets weakly coordinated to the Ni center through the vacant site. The amount of nickel(II) ions in the interlayer

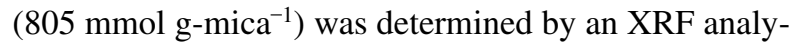
sis, and $23 \%$ of the nickel ions participated in the formation of the metal complexes. Based on both the thermal analysis results and the activity, the calculated turn-over frequency in Run $6\left(\mathbf{L 4} / \mathrm{Ni}^{2+}\right.$-mica combined with TEA) was $18.4 \mathrm{~s}^{-1}$.

Finally, we discuss the activation mechanism of the 
procatalysts. From the value of the basal spacing, both ethylene and $\mathrm{R}_{3} \mathrm{Al}$ were not able to access the complexes located deep inside the interlayer. Therefore, it was considered that the activation of the complex took place at the edge of the stacked lamellae, and the formed active sites produced oligomers and a small amount of polymer. The stacked lamellae were peeled off each other by the growth of the polymer chain, and then the inside complexes became accessible. This activation mechanism was assumed based on the ethylene polymerization using the catalysts consisting of the group IV metallocene complex and the cation exchanged-fluorotetrasilicic mica ${ }^{58)}$. The existence of the induction period and its temperature dependence can be consistently explained by this mechanism. A deeper understanding of detailed activation mechanism is currently in progress.

\section{Acknowledgment}

This work was supported by JSPS KAKENHI Grant Number 63871238.

\section{References}

1) Bianchini, C., Giambastiani, G., Rios, I. G., Mantovani, G., Meli, A., Segarra, A. M., Coor. Chem. Rev., 250, 1391 (2006).

2) Speiser, F., Braunstein, P., Saussine, L., Acc. Chem. Res., 38, 784 (2005).

3) Bianchini, C., Giambastiani, G., Rios, I. G., Mantovani, G., Meli, A., Segarra, A. M., Coor. Chem. Rev., 254, 431 (2010).

4) Wang, S., Sun, W.-H., Redshaw, C., J. Organomet. Chem., in press. (dx. doi. org/10.1016/j. jorganchem.2013.08.021).

5) Gao, R., Sun, W.-H., Redshaw, C., Catal. Sci. Technol., 3, 1172 (2013).

6) Killian, C. M., Johnson, L. K., Brookhart, M., Organometallics, 16, 2005 (1997).

7) Svejda, S. A., Brookhart, M., Organometallics, 18, 65 (1999).

8) Helldörfer, M., Backhaus, J., Milius, W., Alt, H. G., J. Mol. Catal. A: Chem., 193, 59 (2003).

9) Helldörfer, M., Backhaus, J., Milius, W., Alt, H. G., J. Mol. Catal. A: Chem., 197, 1 (2003).

10) Helldörfer, M., Backhaus, J., Alt, H. G., Inrog. Chim. Acta. 351, 34 (2003).

11) Helldörfer, M., Alt, H. G., J. Appl. Polym. Sci., 89, 1356 (2003).

12) Schareina, T., Hillebrand, G., Fuhrmann, H., Kempe, R., Eur. J. Inorg. Chem., 2421 (2001).

13) Wang, L., Sun, W.-H., Han, L., Yang, H., Hu, Y., Jin, X., J. Organomet. Chem., 658, 62 (2002).

14) Shao, C., Sun, W.-H., Li, Z., Hu, Y., Han, L., Catal. Commun., 3, 405 (2002).

15) Spencer, L. P., Altwer, R., Wei, P., Gelmini, L., Gauld, J., Stephan, D. W., Organometallics, 22, 3841 (2003).

16) Jie, S., Zhang, D., Zhang, T., Sun, W.-H., Chen, J., Ren, Q., Liu, D., Zheng, G., Chen, W., J. Organomet. Chem., 690, 1739 (2005).

17) Du, J., Li, L.-J., Li, Y., Inorg. Chem. Commun., 8, 246 (2005).

18) Bluhm, M. E., Folli, C., Walter, O., Döring, M., J. Mol. Catal. A: Chem., 229, 177 (2005).

19) Sun, W.-H., Zhang, S., Jie, S., Zhang, W., Li, Y., Ma, H., Chen, J., Wedeking, K., Fröhlich, R., J. Organomet. Chem., 691, 4196 (2006).

20) Benito, J. M., de Jesús, E., de la Mata, F. J., Flores, J. C.,
Gómez, R., Gómez-Sal, P., Organometallics, 25, 3876 (2006).

21) Zhang, M., Zhang, S., Hao, P., Jie, S., Sun, W.-H., Li, P., Lu, X., Eur. J. Inorg. Chem., 3816 (2007).

22) Wang, L., Zhang, C., Wang, Z.-X., Eur. J. Inorg. Chem., 2477 (2007).

23) Irrgang, T., Keller, S., Maisel, H., Kretschmer, W., Kempe, R., Eur. J. Inorg. Chem., 4221 (2007).

24) Jie, S., Zhang, S., Sun, W.-H., Eur. J. Inorg. Chem., 5584 (2007).

25) Adewuyi, S., Li, G., Zhang, S., Wang, W., Hao, P., Sun, W.-H., Tang, N., Yi, J., J. Organomet. Chem., 692, 3532 (2007).

26) Song, Y., Zhang, S., Deng, Y., Jie, S., Li, L., Lu, X., Sun, W.-H., Kinet. Catal., 48, 664 (2007).

27) Sun, W.-H., Wang, K., Wedeking, K., Zhang, D., Zhang, S., Cai, J., Li, Y., Organometallics, 26, 4781 (2007).

28) Gao, R., Zhang, M., Liang, T., Wang, F., Sun, W.-H., Organometallics, 27, 5641 (2008).

29) Xiao, L., Jie, S., Yingxia Song, Y., Cao, X., Sun, W.-H., J. Organomet. Chem., 693, 3858 (2008).

30) Zhang, M., Gao, R., Hao, X., Sun, W.-H., J. Organomet. Chem., 693, 3867 (2008).

31) Yang, Y., Yang, P., Zhang, C., Li, G., Yang, X.-J., Wu, B., Janiak, C., J. Mol. Catal. A: Chem., 296, 9 (2008).

32) Armitage, A. P., Champouret, Y. D. M., Grigoli, H., Pelletier, J. D. A., Singh, K., Solan, G. A., Eur. J. Inorg. Chem., 4597 (2008).

33) Gao, R., Xiao, L., Hao, X., Sun, W.-H., Wang, F., Dalton Trans., 5645 (2008).

34) Chen, Y., Hao, P., Zuo, W., Gao, K., Sun, W.-H., J. Organomet. Chem., 693, 1829 (2008).

35) Yang, P., Yang, Y., Zhang, C., Yang, X.-J., Hu, H.-M., Gao, Y., Wu, B., Inorg. Chim. Acta, 362, 89 (2009).

36) Li, J., Gao, T., Zhang, W., Sun, W.-H., Inorg. Chim. Acta, 362, 166 (2009).

37) Liu, F.-S., Gao, H.-Y., Song, K.-M., Zhang, L., Zhu, F.-M., Wu, Q., Polyhedron, 28, 1386 (2009).

38) Mukherjee, S., Patel, B. A., Bhaduri, S., Organometallics, 28, 3074 (2009).

39) Kyogoku, K., Yamada, C., Suzuki, Y., Nishiyama, S., Fukumoto, K., Yamamoto, H., Indo, S., Sano, M., Miyake, T., J. Jpn. Petrol. Inst., 53, (5), 308 (2010).

40) Lee, G. M., Appukuttan, V. K., Suh, H., Ha, C.-S., Kim, I., Catal. Lett., 141, 1608 (2011).

41) Chena, X., Zhanga, L., Yub, J., Haob, X., Liub, H., Sun, W.-H., Inorg. Chim. Acta, 370, 156 (2011).

42) Song, S., Xiao, T., Liang, T., Wang, F., Redshaw, C., Sun, W.H., Catal. Sci. Technol., 1, 69 (2011).

43) Song, S., Xiao, T., Wang, L., Redshaw, C., Wang, F., Sun, W.H., J. Organomet. Chem., 699, 18 (2012).

44) Lai, J., Hou, X., Liu, Y., Redshaw, C., Sun, W.-H., J. Organomet. Chem., 702, 52 (2012).

45) Hou, X., Liang, T., Sun, W.-H., J. Organomet. Chem., 708709, 98 (2012)

46) Chandran, D., Lee, K. M., Chang, H. C., Song, G. Y., Lee, J.-E., Suh, H., Kim, I., J. Organomet. Chem., 718, 8 (2012).

47) Chai, W., Yu, J., Wang, L., Hu, X., Redshaw, C., Sun, W.-H., Inorg. Chim. Acta, 385, 21 (2012).

48) Schweinfurth, D., Su, C.-Y., Wei, S.-C., Braunstein, P., Sarkar, B., Dalton Trans., 41, 12984 (2012).

49) Chandran, D., Byeon, S. J., Suh, H., Kim, I., Catal. Lett., 143, 717 (2013).

50) Hao, P., Song, S., Xiao, T., Li, Y., Redshaw, C., Sun, W.-H., Polyhedron, 52, 1138 (2013).

51) Ainooson, M. K., Guzei, I. A., Lara, C., Spencer, L. C., Darkwa, J., Polyhedron, 53, 295 (2013).

52) Rossetto, E., Caovilla, M., Thiele, D., de Souza, R. F., Bernardo-Gusmão, K., Appl. Catal. A: General, 454, 152 
(2013).

53) Kurokawa, H., Matsuda, M., Fujii, K., Ishihama, Y., Sakuragi, T., Ohshima, M., Miura, H., Chem. Lett., 36, 1004 (2007).

54) Fujii, K., Ishihama, Y., Sakuragi, T., Ohshima, M., Kurokawa, H., Miura, H., Catal. Commun., 10, 183 (2008).

55) Kurokawa, H., Nakazato, Y., Tahara, S., Katakura, T., Ishihama, Y., Sakuragi, T., Miura, H., Macromol. React. Eng.,
7, 125 (2013).

56) Kurokawa, H., Miura, K., Yamamoto, K., Sakuragi, T., Sugiyama, T., Ohshima, M., Miura, H., Catalyst, 3, 125 (2013).

57) Johnson, L. K., Killian, C. M., Brookhart, M., J. Am. Chem. Soc., 117, 6414 (1995).

58) Kurokawa, H., Morita, S., Matsuda, M., Suzuki, H., Ohshima, M., Miura, H., Appl. Catal. A: General, 360, 192 (2009).

\title{
要旨
}

\section{フッ素四ケイ素雲母層間に固定化されたフッ素原子置換 $\alpha$-ジイミン配位子を有するニッケル (II) 錯体を 不均一系触媒とするエチレンのオリゴメリゼーション}

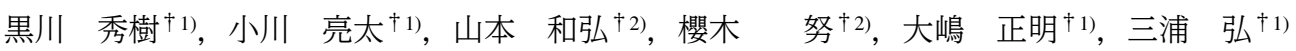 \\ †1) 埼玉大学大学院理工学研究科, 338-8570 さいたま市桜区下大久保 255 \\ †2) 日本ポリケム(株)ポリオレフィン技術センター, 510-8530 三重県四日市市東邦町1
}

ニッケル交換したフッ素四ケイ素雲母と配位子 $\left[\mathrm{Ph}{ }^{\prime}-\mathrm{N}=\right.$ $\mathrm{C}(\mathrm{Me})-\mathrm{C}(\mathrm{Me})=\mathrm{N}-\mathrm{Ph}^{\prime} ; \mathrm{Ph}^{\prime}=\mathrm{C}_{6} \mathrm{H}_{5^{-}}, 2-\mathrm{FC}_{6} \mathrm{H}_{4^{-}}, 4-\mathrm{FC}_{6} \mathrm{H}_{4^{-}}$, $2,4-\mathrm{F}_{2} \mathrm{C}_{6} \mathrm{H}_{3}-$, および2,4,6- $\left.\mathrm{F}_{3} \mathrm{C}_{6} \mathrm{H}_{2}-\right]$ の直接反応により不均一系 $\alpha$-ジイミンニッケル触媒を調製した。調製した触媒を汎用のア ルキルアルミニウム化合物であるトリエチルアルミニウムやト リイソブチルアルミニウムによって活性化すると, 直鎖 $\alpha$-オ レフィン類を生成するエチレンのオリゴメリゼーションに対し て高い触媒活性が容易に得られた。配位子のフェニル基上に フッ素原子を導入すると触媒活性が向上し, 2,4-ジフルオロ
フェニル基を持つ触媒で最高活性が得られた。このフッ素原子 の触媒活性への効果は, フッ素原子がニッケルの電子密度を低 下させたためである。生成したオリゴマーの組成はシュルツ フローリー分布に従い, その定数は $0.53 \sim 0.65$ であった。直鎖 $\alpha$-オレフィンへの選択率は, すべての実験で $90 \mathrm{~mol} \%$ 以上で あった。すべての重合において明瞭な長い誘導期が観測され, それは反応温度を上昇させると短くなった。この興味深い触媒 挙動は, 触媒の特異な層状構造に由来する複雑な活性化メカニ ズムのためと考えられる。 